\title{
Penggunaan Metode World Square dalam Meningkatkan Keterampilan Menulis Pertanyaan Berdasarkan Isi Cerpen pada Siswa Kelas VII SMP Negeri 2 Dompu
}

\begin{tabular}{ll} 
Leni Marlina \\
& STKIP Yapis Dompu, Dompu, Indonesia \\
& *Corponding Author: sayalenimarlina@gmail.com \\
\hline Article history & Abstrak: Penelitian bertujuan untuk meningkatkan hasil \\
& menulis pertanyaan siswa kelas VII SMPN 2 Dompu pada \\
Dikirim: & mata pelajaran Bahasa dan Sastra Indonesia dengan \\
Direvisi: & menggunakan metode Word Square.Penelitian ini adalah \\
24-02-2022 & penelitian tindakan kelas (PTK). Subyek penelitian ini \\
Diterima: & adalah kelas VII berjumlah 32 orang. Prosedur penelitian ini \\
25-02-2022 & terdiri dari dua siklus, setiap siklus dilakukan dengan empat \\
Key words: & kali pertemuan. Instrumen dalam penelitian ini adalah tes \\
\hline Metode Word Square; & hasil belajar, dan lembar observasi. Teknik yang digunakan \\
menulis pertanyaan; isi & untuk pengumpulan data dalam penelitian ini dengan cara \\
cerpen & dokumentasi dan observasi berupa kinerja siswa dan data \\
& tentang hasil belajar siswa diambil dengan menggunakan \\
& teks formatif hasil belajar. Data yang terkumpul dianalisis \\
& dengan menggunakan deskriptif dan kualitatif. Hasil \\
& penelitian menunjukan bahwa rata-rata kemampuan menulis \\
& pertanyaan siswa kelas VII SMPN 2 Dompu pada \\
& pelaksanaan siklus I adalah 67,34 (berkategori cukup), pada \\
& siklus II adalah 75,62 (berkategori baik). Maka dapat \\
& disimpulkan dengan menerapkan metode Word Suare dalam \\
& pembelajaran, hasil belajar menulis pertanyaan siswa kelas \\
& VII pada mata pelajaran Bahasa Indonesia meningkat. \\
& Sebagai aplikasi penelitian ini, disarankan kepada guru agar \\
& memotivasi siswa membaca, menulis, serta melatih dan \\
& membimbing untuk menjawab pertanyaan. \\
\hline &
\end{tabular}

\section{PENDAHULUAN}

Mata pelajaran bahasa Indonesia diarahkan untuk penguasaan bahasa atau belajar berkomunikasi siswa. Oleh karena itu, pembelajaran bahasa Indonesia diarahkan untuk meningkatkan kemampuan peserta didik untuk berkomunikasi dalam bahasa Indonesia dengan baik dan benar, baik secara lisan maupun tulisan, serta menimbulkan penghargaan terhadap hasil cipta manusia Indonesia. Strategi ini pertama kali dikembangkan oleh Frang Lyman dan koleganya di Universitas Maryland sesuai dengan semua resitasi atau diskusi membutuhkan pengatuan untuk mengendalikan kelas secara keseluruhan (Djumingin, 2011:148). Standar kompetensi bahasa dan sastra Indonesia yang merupakan kualifikasi kemampuan minimal peserta didik yang menggambarkan penguasaan pengetahuan, keterampilan berbahasa, dan sikap positif terhadap bahasa dan sastra Indonesia. Selain itu standar kompetensi 
adalah dasar bagi siswa untuk dapat memahami dan mengakses perkembangan lokal, regional, dan global (Rofi'uddin, 1997:182).

Permasalahan pendidikan selalu muncul bersamaan dengan berkembang dan meningkatnya kemampuan siswa, situasi dan kondisi lingkungan yang ada, pengaruh informasi dan kebudayaan, serta berkembangnya ilmu pengetahuan dan teknologi. Guru merupakan kunci dan sekaligus ujung tombak pencapaian misi pembaharuan pendidikan, mereka berada di titik sentral untuk mengatur, mengarahkan dan menciptakan suasana kegiatan belajar mengajar yang untuk mencapai tujuan dan misi pendidikan nasional yang dimaksud. Oleh karena itu, secara tidak langsung guru dituntut untuk lebih profesional, inovatif, perspektif, dan proaktif dalam melaksanakan tugas pembelajaran.

Ruang lingkup mata pelajaran bahasa Indonesia mencakup komponen kemampuan berbahasa dan kemampuan bersastra yang meliputi aspek-aspek mendengarkan, berbicara, membaca, dan menulis. Menulis sebagai salah satu keterampilan dalam pembelajaran bahasa Indonesia di sekolah dasar tidak akan datang secara otomatis, tetapi harus melalui latihan dan praktik banyak dan teratur. Menulis adalah kemampuan seseorang untuk mengungkapkan ide, pikiran, pengetahuan, ilmu dan pengalaman-pengalaman hidupnya dalam bahasa tulis yang runtut, enak dibaca, dan dipahami oleh orang lain (Nababan, 1998:116).

Kemampuan menulis merupakan keterampilan yang sangat penting dalam kehidupan, tidak hanya penting dalam kehidupan pendidikan, tetapi juga sangat penting dalam kehidupan masyarakat. Keterampilan menulis itu sangat penting karena merupakan salah satu keterampilan berbahasa yang harus dimiliki oleh siswa. Dengan menulis siswa dapat mengungkapkan atau mengekspresikan gagasan atau pendapat, pemikiran, dan perasaan yang dimiliki. Selain itu, dapat mengembangkan daya pikir dan kreativitas siswa dalam menulis (Suyatno, 2004:52).

Menulis sebagai suatu keterampilan berbahasa yang dipergunakan untuk berkomunikasi secara tidak langsung. Menulis adalah suatu kegiatan yang aktif dan produktif serta memerlukan cara berpikir yang teratur yang diungkapkan dalam bahasa tulis. Keterampilan seseorang untuk mengungkapkan ide, pikiran, gagasan, pengetahuan, ilmu, dan pengalaman sebagai suatu keterampilan yang produktif (Muliati, 2010; Dinamaryati, 2021). Menulis dipengaruhi oleh keterampilan produktif lainnya, seperti aspek berbicara maupun keterampilan reseptif yaitu aspek membaca dan menyimak serta pemahaman kosakata, diksi, keefektifan kalimat, penggunaan ejaan dan tanda baca. Pemahaman berbagai jenis karangan serta pemahaman berbagai jenis paragraf dan pengembangannya (Nurgiantoro, 2001; Agustina, 2021).

Metode pembelajaran merupakan salah satu aspek penting yang harus diperhatikan oleh guru dalam proses pembelajaran. Metode pembelajaran yang digunakan harus mampu menciptakan suasana yang nyaman bagi siswa dalam mengikuti pelajaran. Disamping itu, dengan metode pembelajaran tersebut, tujuan pembelajaran dapat tercapai secara maksimal. Dalam hal ini terjadi peningkatan baik dari aspek keterampilan matematis siswa maupun hasil belajar siswa. Hal ini sesuai dengan Achmadi (2010:120) yang mengemukakan bahwa di antara tugas utama guru adalah menciptakan suasana atau iklim belajar mengajar yang dapat memotivasi siswa untuk senantiasa belajar dengan baik dan bersemangat. 
Dengan iklim belajar mengajar yang menantang berkompetisi secara sehat serta memotivasi siswa dalam belajar, akan berdampak positif dalam pencapaian prestasi belajar yang optimal. Untuk itu, seyogyanya guru memiliki kemampuan dalam memahami dan melaksanakan metode pembelajaran yang akan digunakan. Konsekuensi logis ketidaktepatan metode pembelajaran sering menimbulkan kebosanan, kurang dipahami, bergaya monolog dan monoton yang akhirnya menyebabkan siswa menjadi apatis. Permasalahan inilah yang terjadi pada proses pembelajaran bahasa Indonesia khususnya dalam membaca cepat pada siswa kelas VII SMPN 2 Dompu.

Pada kesempatan ini, peneliti membahas tentang kemampuan siswa dalam menulis pertanyaan berdasarkan isi cerpen yang di pelajari. Selama ini keterampilan siswa untuk menulis masih sangat terbatas, terlebih lagi untuk dapat menulis pertanyaan. Hal ini disebabkan kurangnya motivasi belajar siswa dalam menulis, kurang kosakata, membaca dan memahami bacaan dan kelemahan-kelemahan guru di kelas yang kurang menekankan aspek menulis dalam pembelajaran bahasa Indonesia. Agar dapat menulis cerpen kadang-kadang siswa perlu dipacu dengan menggunakan teknik dan media yang menarik (Harsono, 2015; Umar, 2016; Puspita, 2020). Oleh karena itu dengan adanya penelitian ini di harapkan mampu mengatasi masalah tersebut.

Sesuai dengan hasil observasi awal peneliti dan keluhan yang diungkapkan oleh salah seorang guru bahwa metode atau strategi yang lazim digunakan adalah metode diskusi kelompok, partisipatori, ceramah, dan lain-lain. Metode ini hanya mampu mengaktifkan 2-3 orang siswa yang pada dasarnya siswa tersebut dari awal memang memiliki kemampuan dan perhatian yang lebih dibandingkan siswa yang lain. Hal inilah yang mendorong peneliti untuk menerapkan metode word square dalam proses pembelajaran menulis (Elimidadiany, 2008:125).

Dalam menulis pertanyaan dibutuhkan adanya ketelitian, kepaduan, keruntutan dan kelogisan antara kalimat satu dengan kalimat yang lain, sehingga akan membentuk sebuah pertanyaan yang baik dan berbobot. Pelly (Hariadi \& Zamzani, 2006: 75) mengemukakan bahwa pembelajaran membaca dan menulis yang dulu merupakan pelajaran dan latihan pokok kini kurang mendapat perhatian, baik dari para siswa maupuan para guru. Pelajaran menulis sebagai salah satu aspek dalam pembelajaran bahasa Indonesia kurang ditangani secara sungguh-sungguh. Akibatnya, kemampuan menulis para siswa kurang memadai.

\section{METODE PENELITIAN}

Penelitian ini merupakan penelitian tindakan kelas (PTK) yang merupakan bentuk kajian yang sistematis reflektif oleh pelaku tindakan yang dilakukan untuk meningkatkan kemantapan rasional dari tindakan mereka dalam melaksanakan tugas, memperdalam pemahaman terhadap tindakan-tindakan yang dilakukannya itu, serta memperbaiki kondisi pembelajaran. Penelitian tindakan kelas bersifat reflektif artinya dalam proses penelitian, guru sekaligus sebagai peneliti yang memikirkan apa dan mengapa suatu tindakan terjadi di kelas, dari pemikiran itu kemudian guru mencari pemecahannya melalui tindakan-tindakan tertentu (Arikunto, 2009: 7). Penelitian tindakan kelas ini dilaksanakan dalam bentuk II siklus yang terdiri atas

@2022 DIKSI (https://jurnal.bimaberilmu.com/index.php/diksi) 
empat tahapan pelaksanaan, yakni: 1) perencanaan, 2) tindakan, 3) observasi, dan 4) refleksi.

Penelitian ini dilaksanakan di SMPN 2 Dompu pada semester ganjil tahun pelajaran 2020/2021. Subjek penelitian ini ialah siswa kelas VII SMPN 2 Dompu dengan jumlah siswa 32 orang yang terdiri dari 17 laki-laki dan 15 perempuan. Adapun teknik pengumpulan data yang dilakukan pada penelitian ini ialah data mengenai tingkat penguasaan materi yang diambil dari tes setiap akhir siklus. Tes dibuat oleh penulis bekerja sama dengan guru mata pelajaran. Data tentang proses belajar mengajar dalam hal kerajinan, kesungguhan siswa mengikuti proses pembelajaran, keterampilan siswa dalam melakukan kerjasama dan rasa percaya diri diambil pada saat dilakukannya tindakan dengan menggunakan lembar observasi. Analisis data dalam penelitian ini adalah analisis kualitatif.

\section{HASIL DAN PEMBAHASAN}

Hasil penelitian proses pembelajaran keterampilan menulis pertanyaan dengan penerapan metode Word Square yang di dahului dengan pratindakan. Hal tersebut dilakukan untuk memperjelas permasalahan yaitu mengetahui kemampuan menulis pertanyaan siswa sebelum diterapkan metode Word Square. Deskripsi proses pelaksanaan tindakan yang terdiri atas dua siklus. Refleksi dan diskusi antara peneliti dan guru kelas dan kepala sekolah disepakati untuk merancang pembelajaran menulis pertanyaan dengan menerapkan metode word square agar prestasi menulis pertanyaan siswa dapat meningkat.

\section{Pelaksanaan Siklus I}

1. Rencana Tindakan

Setelah guru menetapkan untuk menerapkan metode word square dalam bacaan, kegiatan selanjutnya adalah menyiapkan hal-hal yang diperlukan pada saat pelaksanaan tindakan siklus I. Hal-hal yang dipersiapkan adalah sebagai berikut:

a. Membuat rencana pembelajaran sesuai dengan yang disepakati pada kegiatan awal yaitu belajar menulis pertanyaan melalui metode Word Square.

b. Membuat lembar observasi terhadap guru dan siswa

c. Membuat LKS sebagai alat evaluasi

2. Pelaksanaan Tindakan

Pada siklus I, pelaksanaan pembelajaran menulis sesuai dengan rencana pelaksanaan pembelajaran yang telah disusun oleh guru bersama peneliti yaitu menerapkan metode word square untuk meningkatkan kemampuan menulis siswa. Pada tanggal 24 Agustus 2020 dikelas VII SMPN 2 Dompu merupakan pertemuan awal pelaksanaan proses pembelajaran. Pertama-tama guru mengajukan beberapa pertanyaan yang berkaitan dengan materi kegiatan yang ingin dilakukan untuk menarik perhatian siswa mengikuti pelajaran sekaligus mengecek kemampuan awal sesuai kompetensi dasar.

Adapun pertanyaan yang diajukan antara lain: (1) pernahkah kalian membaca cerita pendek? (2) cerita apa saja yang pernah kalian baca? Selanjutnya kegiatan ini dilaksanakan dengan menerapkan metode Word Square dengan mengikuti tahap sebagai berikut:

a. Guru menyampaikan materi sesuai kompetensi yang ingin dicapai. 
b. Guru membagikan lembaran kegiatan sesuai contoh.

c. Siswa menjawab soal kemudian mengarsir huruf dalam kotak sesuai jawaban.

d. Memberikan poin setiap jawaban dalam kotak.

Pada akhir pembelajaran guru memberikan arahan kepada siswa untuk membaca kembali teks bacaan yang telah di ajarkan, kemudian siswa tersebut di beri tugas membuat soal jawab dari wacana yang telah dibaca untuk mengukur kemampuan siswa dalam memahami teks bacaan, dengan judul wacana"Ulang Tahun Ibu Kartini”. Adapun pertanyaan yang dibuat oleh siswa setelah membaca teks bacaan yaitu: 1 Sebutkanlah tokoh - tokoh yang diceritakan dalam cerpen yang kalian baca?, 2) Dimanakah latar tempat cerita tersebut?, 3) Siapakah tokoh utama cerpen yang kalian baca?, 4) Siapakah nama guru yang ulang tahun?, 5) Hari kelahiran R. A. Kartini tepat pada tanggal berapa?, 6) Bagaimanakah latar belakang nama Ibu Kartini!, 7) Apakah sama hari kelahiran R. A. Kartini dengan Kartini!, 8) Apakah hadiah ulang tahun Ibu Kartini!, 9) Apakah harapan Ibu Kartini di hari ulang tahunnya? 10) Apakah tema cerpen tersebut?

Pembelajaran ini diikuti oleh 32 orang siswa. Pada siklus I, metode Word Square yang diterapkan belum sempurna yaitu pada tahap-tahap Word Square karena guru kurang mengarahkan pada kegiatan tersebut. Hal tersebut berdampak pada kemampuan siswa melaksanakan kegiatan selanjutnya yang berakibat rendahnya prestasi siswa pada perolehan skor hasil tes pada tabel berikut ini:

Tabel 1. Data hasil kemampuan siswa menulis pertanyaan pada siklus I

\begin{tabular}{|c|c|l|}
\hline Jumlah siswa & Presentase & \multicolumn{1}{|c|}{ Kategori } \\
\hline 2 & 6,25 & Sangat Baik \\
\hline 23 & 71,87 & Baik \\
\hline 2 & 6,25 & Cukup \\
\hline 3 & 9,37 & Kurang \\
\hline 2 & 6,25 & Sangat kurang \\
\hline 32 & $\mathbf{1 0 0}$ & C \\
\hline
\end{tabular}

Data tersebut dapat di jelaskan bahwa prestasi siswa menulis pertanyaan pada siklus 1 mencapai skor rata-rata kelas 67,34 Prestasi tersabut berada kualifikasi $\mathrm{C}$, data menunjukkan bahwa ada 2 orang siswa yang mendapat nilai cukup 3 orang siswa mendapat nilai kurang, dan 2 orang siswa mendapat nilai kurang sekali, dengan demikian masih ada 2 siswa atau 6,25 persen siswa berkemampuan di bawah kategori baik.

3. Observasi

Hal-hal yang diobservasi pada pelaksanaan tindakan siklus I adalah cara guru menyajikan materi pelajaran. Apakah sudah sesuai dengan rancangan pembelajaran atau belum. Selain itu juga dilihat aktivitas siswa dalam mengikuti pelajaran. Hasil observasi terhadap guru dan siswa menunjukkan beberapa kelemahan yang nampak dalam pelaksanaan belajar word square yang mempengaruhi peningkatan prestasi belajar siswa.

4. Refleksi

Berdasarkan hasil observasi pada pelaksanaan tindakan siklus I belum mencapai Indikator kinerja yang di harapkan. Dengan kata lain masih ada kekuarangan atau kelemahan-kelamahan yang terjadi. Maka dilakukan refleksi dan siklus balikan atau membahas langkah-langkah pemecahannya sebagai berikut: 
a. Guru mengarahkan dan menjelaskan latar belakang kelahiran Kartini, amanat/pesan dalam wacana "Ulang Tahun Ibu Kartini"

b. Guru mengefisienkan waktu yang dipergunakan dengan cara memberikan estimasi waktu pada setiap membahas wacana "Ulang Tahun Ibu Kartini ".

\section{Pelaksanaan Siklus II}

\section{Rencana Tindakan}

Berdasarkan hasi observasi dan refleksi pada peaksanaan siklus 1, peneliti dan guru merencanakan tindakan siklus II dengan harapan kekurangan yang terdapat pada siklus I dapat diminimalis. Hal- hal yang dilakukan guru dalam memperbaiki kekurangan pada siklus I yaitu sebagai berikut:
a. Rencana Pelaksanaan Pembelajaran
b. Membuat LKS
c. Membuat lembar observasi untuk guru dan siswa
d. Guru harus mengamati setiap siswa pada semua tahapan
e. Guru harus banyak membimbing siswa dengan mengarahkan untuk secara aktif dalam bekerja sama mengefisienkan waktu.

2. Pelaksanaan tindakan

Pada siklus II seperti halnya siklus I, pelaksanaan pembelajaran membaca dan menulis sesuai dengan rencana pelaksanaan pembelajaran yang telah disusun oleh guru bersama peneliti yaitu menerapkan metode word square untuk meningkatkan kemampuan siswa menulis pertanyaan yang difokuskan pada kelemahan yang ditemukan pada siklus I yaitu tahap word square dan pembahasan masing-masing topik yang akan di bahas pada tahapan tersebut dengan menerapkan seluruh komponen word square. Hal-hal yang perlu dilaksanakan oleh guru yaitu menuntun dan meningkatkan partisipasi siswa untuk mengungkapkan topik dan merencanakan suatu tindakan selanjutnya agar proses pembelajaran dapat terlaksana dengan baik sehingga mencapai sasaran atau suatu tujuan yang hendak dicapai oleh guru dan siswa.

Selanjutnya kegiatan ini dilaksanakan dengan menerapkan metode word square dengan mengikuti tahap sebagai berikut:

a. Guru menyampaikan materi sesuai kompetensi yang ingin dicapai.

b. Guru membagikan lembaran kegiatan sesuai contoh.

c. Siswa menjawab soal kemudian mengarsir huruf dalam kotak sesuai jawaban.

d. Memberikan poin setiap jawaban dalam kotak.

Setelah melakukan proses pembelejaran selama 4 kali pertemuan pada siklus II. Peneliti kembali mengarahkan kepada siswa untuk membaca teks bacaan yang telah diajarkan selama pertemuan pada siklus II dan siswa diberi tugas agar membuat pertanyaan serta dijawab sendiri sesuai dengan pemahamannya tentang wacana tersebut. Adapun judul teks bacaan "Ngaret". Kemudian timbul pertanyaan dari siswa yaitu: 1) Sebutkan tokoh-tokoh dalam cerpen ngaret? 2) Dimanakah latar cerita tersebut? 3) Siapakah tokoh utama cerpen tersebut? 4) Jelaskan tema cerpen "NGARET" yang kalian baca? 5) Siapakah nama guru fisika yang mengajar di kelas $\mathrm{X}$ ?

Setelah melakukan observasi pada siklus II terjadi perubahan sikap, pemahaman siswa dalam mengikuti proses pembelajaran. Hal ini dapat dilihat dari hasil tes kemampuan siswa. 
Tabel 2. Data hasil kemampuan siswa dalam menulis pertanyaan pada siklus II

\begin{tabular}{|c|c|l|}
\hline Jumlah siswa & Presentase & \multicolumn{1}{|c|}{ Kategori } \\
\hline 8 & 25 & Sangat Baik \\
\hline 18 & 56,25 & Baik \\
\hline 6 & 18,75 & Cukup \\
\hline- & - & Kurang \\
\hline- & - & Sangat kurang \\
\hline 32 & $\mathbf{1 0 0}$ & B \\
\hline
\end{tabular}

Data tersebut dapat di jelaskan bahwa prestasi siswa menulis pertanyaan pada siklus II mencapai skor rata-rata kelas 75,62 Prestasi tersabut berada kualifikasi B data menunjukkan bahwa ada 6 orang siswa yang mendapat nilai cukup, 9, dan tidak ada siswa mendapat nilai kurang, kurang sekali, dengan demikian 8 orang siswa atau 25 persen siswa berkemampuan atau kategori baik (B).

3. Observasi

Hal-hal yang diobservasi pada pelaksanaan tindakan siklus II yaitu cara guru menyajikan materi lebih terarah pada rancangan pembelajaran yang telah disusun. Selain itu juga dilihat aktivitas siswa dalam mengikuti pelajaran ada peningkatan dan termotivasi untuk belajar membaca.

4. Refleksi

Berdasarkan hasil observasi pada pelaksanaan tindakan siklus II telah mencapai Indikator kinerja yang di harapkan.

\section{Pembahasan}

Hasil penelitian ini akan memberikan gambaran tentang hasil belajar bahasa Indonesia setelah diterapkan metode word square pada siswa kelas VII SMPN 2 Dompu melalui analisis data kualitatif pada siklus I dan siklus II. Dalam penelitian ini yaitu data kualitatif yang diperoleh melalui lembar observasi siswa pada setiap pertemuan, selama jalannya kegiatan pembelajaran mulai dari pertemuan awal hingga akhir pertemuan. Aktifitas yang diamati antara lain: aktivitas siswa dalam mengikuti kegiatan pembelajaran yang disesuaikan dengan lembar observasi siswa.

Analisis kualitatif digunakan untuk menganalisis data perubahan keaktifan siswa yang diperoleh dari lembar observasi siswa. Adapun beberapa yang menjadi indikator dalam lembar observasi siswa yaitu: Hasil analisis kualitatif ini akan memberikan gambaran tentang perubahan sikap dan aktifitas siswa dalam mengikuti pelajaran berdasarkan tindakan pengajaran, adapun perubahan tersebut yansg terjadi pada siklus I dan II adalah sebagai berikut:

\section{a. Siklus I}

Data aktifitas siswa pada siklus I diperoleh melalui hasil pengamatan aktifitas dan sikap siswa selama proses pembelajaran di setiap pertemuan. Adapun deskripsi aktifitas siswa pada siklus I dapat dilihat pada tabel berikut:

Tabel 3. Distribusi Frekuensi Aktifitas dan Sikap Siswa pada Siklus I

\begin{tabular}{|l|c|c|c|c|c|c|}
\hline \multirow{2}{*}{ Kriteria Penilaian } & \multicolumn{4}{|c|}{ Pertemuan } & Persentase \\
\cline { 3 - 7 } & $\mathbf{1}$ & $\mathbf{2}$ & $\mathbf{3}$ & $\mathbf{4}$ & $\mathbf{5}$ & $(\boldsymbol{\%})$ \\
\hline Kehadiran & 27 & 28 & 28 & 32 & Tes & 28.72 \\
\hline Ketepatan waktu mengikuti & 32 & 29 & 30 & 32 & Siklus & 30.75 \\
\hline
\end{tabular}




\begin{tabular}{|l|l|l|l|l|l|c|}
\hline pelajaran & & & & & I & \\
\hline Berpakaian rapi di sekolah & 25 & 28 & 24 & 29 & & 26.5 \\
\hline Kelengkapan buku catatan & 20 & 27 & 30 & 32 & & 27.25 \\
\hline Mengumpulkan tugas & 25 & 25 & 30 & 30 & & 27.5 \\
\hline Mengajukan pertanyaan & 5 & 7 & 5 & 6 & & 5.75 \\
\hline Masih memerlukan bimbingan & 18 & 10 & 5 & 2 & & 8.75 \\
\hline Membuat kesimpulan & 3 & 2 & 4 & 1 & & 2.5 \\
\hline
\end{tabular}

Berdasarkan Tabel 3 di atas diperoleh bahwa dari 32 siswa kelas VII SMPN 2 Dompu, kehadiran siswa rata-rata mencapai $28,72 \%$. Siswa yang mengikuti pelajaran dengan tepat waktu rata-rata $30,75 \%$, siswa yang berpakaian rapi rata-rata $26,5 \%$. Kemudian kelengkapan buku catatan siswa mencapai $27,25 \%$, siswa yang mengumpulkan tugas mencapai $27,5 \%$, siswa yang mengajukan pertanyaan mencapai $5,75 \%$, kemudian siswa yang membuat kesimpulan $2,5 \%$ dan siswa yang masih memerlukan bimbingan mencapai $8,75 \%$.

\section{b. Siklus II}

Data aktifitas siswa pada siklus II diperoleh melalui hasil pengamatan aktifitas dan sikap siswa selama proses pembelajaran di setiap pertemuan. Adapun deskripsi aktifitas siswa pada siklus II dapat dilihat pada Tabel 4 berikut:

Tabel 4. Distribusi Frekuensi Aktifitas dan Sikap Siswa pada Siklus II

\begin{tabular}{|c|c|c|c|c|c|c|}
\hline \multirow{2}{*}{ Kriteria Penilaian } & & \multicolumn{4}{|c|}{ Pertemuan } & \multirow{2}{*}{$\begin{array}{c}\text { Psentase } \\
(\%)\end{array}$} \\
\hline & 6 & 7 & 8 & 9 & $\mathbf{1 0}$ & \\
\hline Kehadiran & 31 & 31 & 32 & 32 & \multirow{8}{*}{$\begin{array}{l}\text { Tes } \\
\text { Siklu } \\
\text { s } \\
\text { II }\end{array}$} & 31.5 \\
\hline Ketepatan waktu mengikuti & 31 & 32 & 32 & 32 & & 31.75 \\
\hline Berpakaian rapi di sekolah & 26 & 25 & 27 & 30 & & 27 \\
\hline Kelengkapan buku catatan & 23 & 32 & 30 & 32 & & 29.25 \\
\hline Mengumpulkan tugas & 29 & 30 & 32 & 32 & & 30.75 \\
\hline Mengajukan pertanyaan & 4 & 6 & 5 & 10 & & 6.5 \\
\hline Masih memerlukan bimbingan & 10 & 8 & 8 & 6 & & 8 \\
\hline Membuat kesimpulan & 10 & 20 & 27 & 26 & & 20.75 \\
\hline
\end{tabular}

Berdasarkan Tabel 4 di atas diperoleh behwa dari 27 siswa kelas VII SMPN 2 Dompu, kehadiran siswa rata-rata mencapai $31,5 \%$. Siswa yang mengikuti pelajaran dengan tepat waktu rata-rata $31,75 \%$, siswa yang berpakaian rapi rata-rata $27,00 \%$. Kemudian kelengkapan buku catatan siswa mencapai $29,25 \%$, siswa yang mengumpulkan tugas mencapai $30,75 \%$, siswa yang mengajukan pertanyaan mencapai $6,5 \%$, kemudian siswa yang membuat kesimpulan $20,75 \%$ dan siswa yang masih memerlukan bimbingan mencapai $8,00 \%$. Sebagaimana hasil penelitian tentang penggunaan metode pembelajaran word square yang dapat meningkatkan hasil belajar siswa (Swapranata dkk, 2016; Febriani, \& Lucyana, 2018).

Dari perubahan-perubahan sikap dan keaktifan siswa dalam proses belajar mengajar yang terjadi dikelas, maka dapat disimpulkan bahwa dengan diterapkan tindakan pengajaran yaitu melalui metode word square dalam proses pembelajaran siswa akan lebih termotivasi, tertarik atau ada dorongan untuk aktif memberikan tanggapan atau menyelesaikan soal-soal yang diberikan. Dengan demikian maka penggunaan tindakan dalam penelitian ini dapat dikatakan efektif untuk diterapkan dalam proses belajar mengajar. 


\section{KESIMPULAN}

Pertama, Perubahan dari segi kognitif terjadi peningkatan setelah menerapkan metode word square. Ini dibuktikan dengan melihat skor tes rata-rata siswa pada siklus pertama yaitu 67,34 dan pada siklus kedua meningkat dengan skor rata-rata siswa yaitu 75,62. Kedua, Selain perubahan dari segi kognitif, segi afektif siswa kelas VII SMPN 2 Dompu, juga mengalami perubahan setelah dilakukan penerapan metode word square, hal itu terlihat dari meningkatnya keinginan siswa untuk menulis dan membaca lebih giat dan merespon dengan baik tugas-tugas individu yang diberikan. Ketiga, Tidak hanya itu, psikomotorik siswa juga terlihat jelas terjadi peningkatan. Itu terlihat dari keaktifan siswa dalam membaca dan menulis.

\section{Saran}

Pertama, Dalam pengembangan pembelajaran bahasa Indonesia, khususnya keterampilan menulis dan membaca dalam rangka memacu kreativitas siswa, maka tepat kiranya bila diterapkan metode word square. Kedua, Bagi instansi terkait, hasil penelitian tindakan kelas ini diharapkan dapat menjadi bahan masukan untuk memperbaiki atmosfir pembelajaran dalam rangka peningkatan keterampilan menulis siswa maupun guru. Ketiga, Untuk peneliti dalam bidang yang sama, hasil penelitian sini dapat menjadi acuan dalam melakukan penelitian lanjutan, karena hasil penelitian ini masih sangat terbatas dan terbilang sederhana, baik dalam lingkup kajiannya maupun hasil-hasil penelitian yang diperoleh.

\section{DAFTAR PUSTAKA}

Achmadi. (2010). Membangun Motivasi Menulis. Bandung: Citra Aditya Bakti.

Agustina, A. (2021). Peningkatan Prestasi Belajar Siswa pada Pelajaran Bahasa Indonesia Materi Menulis Teks Resensi dengan Menerapkan Model Pembelajaran Kooperatif Tipe Think Pair Share (TPS) di Kelas XI MIPA 1 SMAN 2 Bolo Semester II Tahun Pelajaran 2020/2021. Jurnal Pendidikan dan Pembelajaran Indonesia (JPPI), 1(2), 316-327.

Arikunto, S. (2009). Penelitian Tindakan Kelas. Jakarta: PT Bumi Aksara.

Dinamaryati, D. (2021). Penerapan Pendekatan Pembelajaran Berbasis Genre dengan Media Pembelajaran Kartu Topik untuk Meningkatkan Prestasi Belajar Siswa pada Mata Pelajaran Bahasa Indonesia Materi Menyusun Teks Tanggapan di SMPN 4 Bolo Kelas IX-3 Semester I Tahun Pelajaran 2020/2021. Jurnal Pendidikan dan Pembelajaran Indonesia (JPPI), 1(2), 328-339.

Djumingin, S. (2011). Strategi Dan Aplikasi: Model Pembelajaran Inovatif Bahasa dan Sastra. Makassar: Badan Penerbit Universitas Negeri Makassar.

Elimidadiany, Novi. (2008). Metode word square. (Online), (http://mforum.cari.my/redirect.php?tid=11894\&goto=lastpost. Html, diakses18 Maret 2012).

Febriani, R., \& Lucyana, S. (2018). Penerapan Model Pembelajaran Word Square untuk Meningkatkan Hasil Belajar Siswa Kelas X Pada Mata Pelajaran Akuntansi Perusahaan Jasa Di SMK Pasundan 1 Kota Serang. Progress: Jurnal Pendidikan, Akuntansi Dan Keuangan, 1(1), 80-94. 
Hariadi \& Zamzani. (2006). Peningkatan Keterampilan Berbahasa Indonesia. Bagian Proyek Pengembangan Pendidikan Guru Sekolah Dasar. Jakarta: Dirjen Dikti Depdiknas.

Harsono, B. (2015). Peningkatan Keterampilan Menulis Cerpen Melalui Teknik Latihan Terbimbing Dengan Media Teks Lagu Siswa Kelas 9 Smp Negeri 1 Boyolangu Tulungagung. PINUS: Jurnal Penelitian Inovasi Pembelajaran, 1(2).

Muliati. (2010). Meningkatkan Kemampuan Menulis Karangan Deskripsi Melalui Penerapan Pendekatan Proses Pada Siswa Kelas V SD No. 21 Inpres Marana. UNISMUH Makassar: Tidak di terbitkan.

Nababan, P.W.J. (1998). Pengajaran Bahasa dan Pendekatan prakmatik. Jakarta: IKIP Jakarta.

Nurgiantoro, A. (2001). Memotivasi Minat Menulis. Jakarta: Gramedia Pustaka

Puspita, R. (2020). Peningkatan Keterampilan Menulis Cerpen Menggunakan Teknik Terbimbing Dengan Media Cerpen Siswa Kelas IX A SMP-IT Ar Rahmah Pacitan. Sarasvati, 2(1), 78-87.

Rofi'uddin, A. (1997). Evaluasi Pembelajaran Bahasa Indonesia. Vocal. Th. V. ssNo.7. Hal 65-81.

Suyatno. (2004). Teknik Pembelajaran Bahasa dan Sastra. Surabaya: SIC.

Swapranata, A. N. A., Riastini, P. N., \& Japa, I. G. N. (2016). Penerapan Model Pembelajaran Word Square Untuk Meningkatkan Hasil Belajar Ipa Siswa Kelas V Semester Genap Di Sd Negeri 1tista Tahun Pelajaran 2015/2016. Mimbar PGSD Undiksha, 4(2).

Umar, S. (2016). Peningkatan Keterampilan Menulis Cerpen dengan Strategi Copy The Master Melalui Media Audiovisual pada Siswa Kelas IXa SMP Negeri 2 Tolitoli. Jurnal Kreatif Tadulako, 4(6), 119579. 